\title{
PERCUTANEOUS PEDICLE FIXATION OF THORACOLUMBAR VERTEBRAL FRACTURES WITHOUT NEUROLOGICAL DEFICITS
}

\author{
FIXAÇÃO PEDICULAR PERCUTÂNEA DE FRATURAS VERTEBRAIS TORACOLOMBARES \\ SEM COMPROMISSO NEUROLÓGICO
}

\author{
FIJACIÓN PEDICULAR PERCUTÁNEA DE LAS FRACTURAS VERTEBRALES \\ TORACOLUMBARES SIN COMPROMETIMIENTO NEUROLÓGICO
}

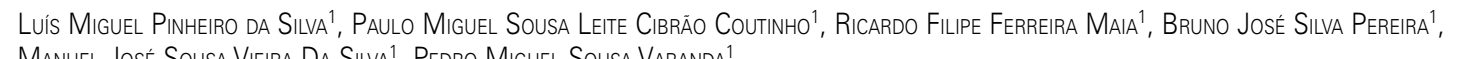
Manuel José Sousa Vieira Da Silva', Pedro Miguel Sousa Varanda ${ }^{1}$

\begin{abstract}
Objective: To evaluate the efficacy and safety of percutaneous pedicle fixation in thoracolumbar fractures without neurologic compromise. Methods: The study included patients aged between 18 and 70 with $\mathrm{AO}$ thoracolumbar fracture type (A.3) and kyphosis $>30^{\circ}$ or reduction of vertebral body height $>50 \%$ or $>50 \%$ of spinal canal compromise, who underwent surgery with percutaneous pedicle fixation in the first ten days after fracture. Radiological parameters were evaluated: Cobb angle, vertebral collapse, anterior wedging and spinal canal compromise preoperatively, postoperatively and at the end of follow-up. The clinical and functional outcome was assessed by the Oswestry Disability Index (ODI). Results: Mean operative time was 81 minutes (Min 69, Max 95 min). The mean volume of intraoperative blood loss was $85 \mathrm{ml}$ (75 Min and Max $155 \mathrm{ml}$ ). The mean follow-up was seven months (3 months Min, Max, 14 months) with an average ODI of 18\% (excellent). Conclusions: The clinical results suggest that the pedicle fixation percutaneous technique may be an alternative to surgical treatment of thoracolumbar fractures type (A.3), without neurological deficits. This technique has proved to be safe and effective, with the advantages of a minimally invasive approach.
\end{abstract}

Keywords: Spine; Spinal fractures; Surgical procedures, minimally invasive; Fracture fixation, internal; Lumbar vertebrae; Thoracic vertebrae.

\section{RESUMO}

Objetivo: Avaliar a eficácia e a segurança da fixação pedicular percutânea em fraturas toraco-lombares, sem compromisso neurológico. Métodos: Foram incluídos no estudo os pacientes com idade compreendida entre os 18 e 70 anos com fratura toracolombar AO tipo (A.3), cifose $>30^{\circ}$ ou redução da altura do corpo vertebral $>50 \%$ ou compressão do canal vertebral $>50 \%$ que foram submetidos a tratamento cirúrgico com fixação pedicular percutânea. Foram avaliados os parâmetros radiológicos: ângulo de Cobb, colapso vertebral, acunhamento anterior e compressão do canal vertebral no pré-operatório, pós-operatório e no fim do seguimento. O resultado funcional e clínico foi avaliado pelo Oswestry Disability Index (ODI). Resultados: O tempo operatório médio foi de 81 minutos (Mín. 69, Máx. $95 \mathrm{~min}$ ). O volume médio de perda sanguínea intraoperatória foi de $85 \mathrm{ml}$ (Mín. 75 e Máx. 155 ml). O seguimento médio foi de sete meses (Min. três meses, Máx. 14 meses). Apresentaram um ODI médio final de 18\% (excelente). Conclusões: Os resultados clínicos sugerem que a fixação pedicular percutânea pode ser uma técnica cirúrgica alternativa para o tratamento das fraturas toracolombares AO tipo (A.3), sem défices neurológicos. Esta técnica demonstrou ser eficaz e segura, apresentando as vantagens de uma abordagem minimamente invasiva.

Descritores: Coluna vertebral; Fraturas da coluna vertebral; Procedimentos cirúrgicos minimamente invasivos; Fixação interna de fraturas; Vértebras lombares; Vértebras torácicas.

\section{RESUMEN}

Objetivo: Evaluar la eficacia y la seguridad de la fijación percutánea pedicular de fracturas toracolumbares sin comprometimiento neurológico. Métodos: Se incluyeron en el estudio los pacientes de edades comprendidas entre 18 y 70 años, con fractura toracolumbar tipo AO (A.3), cifosis $>30^{\circ}$ o reducción de la altura del cuerpo vertebral $>50 \%$ o compresión del canal vertebral $>50 \%$, quienes fueron sometidos a tratamiento quirúrgico mediante fijación percutánea pedicular. Se evaluaron los parámetros radiológicos: el ángulo de Cobb, el colapso vertebral, el acuñamiento anterior y la compresión del canal vertebral antes de la operación, después de la operación y al final del seguimiento. La evolución clínica y funcional fue evaluada por el Oswestry Disability Index (ODI). Resultados: El tiempo quirúrgico promedio fue 81 minutos (mínimo 69, máximo 95 min.) El volumen promedio de la pérdida de sangre intraoperatoria fue $85 \mathrm{ml}$ (mínimo 75 y máximo $155 \mathrm{ml}$ ). El promedio de seguimiento fue siete meses (mínimo 3 meses, máximo 14 meses). Se presentó un ODI promedio final de 18\% (excelente). Conclusiones: Los resultados clínicos sugieren que la fijación percutánea pedicular puede ser una técnica quirúrgica alternativa para el tratamiento de las fracturas toracolumbares tipo AO (A.3), sin déficits neurológicos. Esta técnica ha demostrado ser eficaz y segura, y presenta las ventajas de un enfoque mínimamente invasivo.

Descriptores: Columna vertebral; Fracturas de la columna vertebral; procedimientos quirúrgicos mínimamente invasivos; Fijación interna de fracturas; Vértebras lumbares; Vértebras torácicas.

1. Department of Orthopedics and Traumatology, Hospital de Braga, Braga, Portugal. 


\section{INTRODUCTION}

Burst fractures are relatively common injuries in the thoracolumbar spine.

However, treatment of $\mathrm{AO}$ type (A3) unstable thoracolumbar fractures is still controversial, especially for patients with no neurological deficits. Although nonsurgical treatment has been described in several articles with good results, it is also well known that this type of treatment has several complications, including the worsening of kyphosis, consequences of prolonged bed rest, long period of recovery, and possible worsening/development of neurological deficits. ${ }^{1,2}$

Surgical treatment has demonstrated better clinical and radiological results. It allows for immediate stabilization of the spine, restoration of sagittal alignment, and the possibility of spinal canal decompression. 3,4

However, the classical (open) surgical approach with pedicle fixation (short or long segment) involves extensive exposure and dissection, which is generally associated with a high rate of morbidity: high intraoperative blood loss, and significant infection and muscle injury rates. ${ }^{5,6}$ Minimally invasive surgery, in particular percutaneous pedicle fixation, has become increasingly popular in spinal surgery.

The technique of placing pedicle screws percutaneously was initially introduced by Magerl in $1977 .{ }^{7} \mathrm{Kim}$ et al. ${ }^{8}$ proved that percutaneous pedicle fixation causes less muscle damage than open pedicle fixation techniques.

The aim of this prospective study was to evaluate the efficacy and safety of percutaneous pedicle fixation using a minimally invasive technique for $\mathrm{AO}$ type (A.3) thoracolumbar fractures.

\section{MATERIAL AND METHODS}

Inclusion criteria were: AO type (A.3) thoracolumbar fracture; kyphosis $>30^{\circ}$ and/or reduction of vertebral body height $>50 \%$ and/or compression of the spinal canal $>50 \%{ }^{9}$ Exclusion criteria were: age less than 18 years or over 70 years, impossibility of surgical treatment in the first ten days after the injury, and the presence of neurological deficits. The study took place between December 2010 and December 2011. Twenty-three adult patients were included in this study, 12 were male and 11 female. The average age was 49.4 years (minimum of 24 and maximum of 68). As for the distribution of fractures by vertebral level, we obtained three cases affecting T8, one T9, one T11, four cases $T 12$, ten $L 1$, two $L 2$, one $L 3$, and one L4. The mechanism of injury included: 20 cases of falling from heights, two pedestrians being run over and one car crash. (Table 1)

The pre- and postoperative evaluation during follow-up was performed using radiography (Figure 1) and CAT of the thoracolumbar spine. (Figure 2) The radiological parameters evaluated were the Cobb angle, reduction of the height of the vertebral body, anterior wedging of the fractured vertebra, and compression of the spinal

Table 1. Demographics of the study population.

\begin{tabular}{c|c}
\hline Variable & No. of patients \\
\hline Sex & 12 \\
\hline Male & 11 \\
\hline Female & \\
\hline Level of fracture & 3 \\
\hline T8 & 1 \\
\hline T9 & 1 \\
\hline T11 & 4 \\
\hline T12 & 10 \\
\hline L1 & 2 \\
\hline L2 & 1 \\
\hline L3 & 1 \\
\hline L4 & 20 \\
\hline Mechanism of injury & 2 \\
\hline Fall from a height & 1 \\
\hline Run over & \\
\hline Car crash & \\
\hline
\end{tabular}

canal. The sagittal curvature was measured by the Cobb angle (defined as the angle between the upper surface of the vertebral body above the fracture and the bottom surface of the vertebral body at the level below the fracture).$^{10}$ Patients were evaluated at one, three, six, and 12 months postoperatively, clinically, the Oswestry Disability Index was collected, and radiographically and with CAT at three or six months.

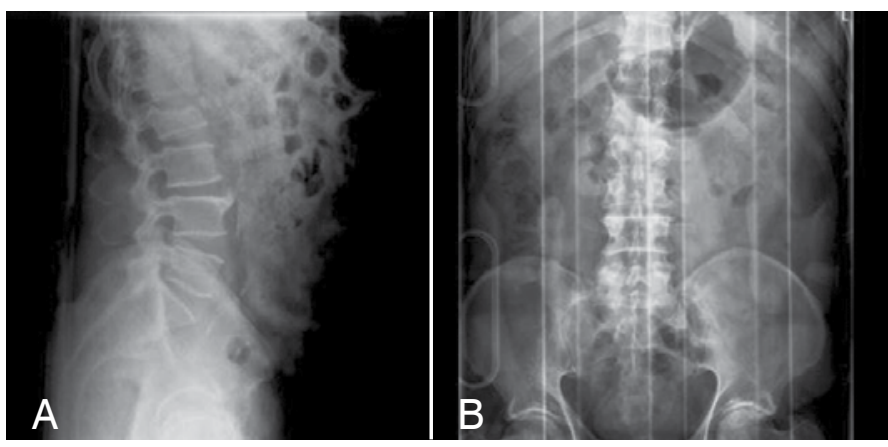

Figure 1. Preoperative radiograph of a type L2 burst fracture. A) Lateral, B) Anteroposterior.
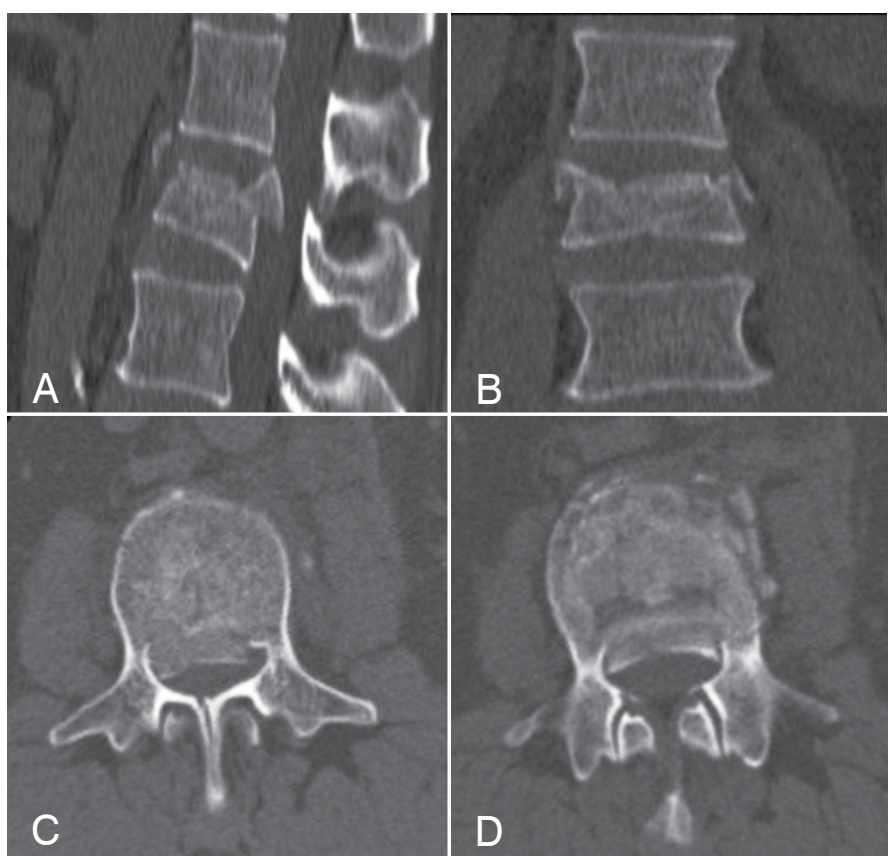

Figure 2. Preoperative CAT of a type L2 burst fracture: A) Sagittal, B) Coronal, C and D) Axial.

\section{Surgical technique}

All patients were treated with the CD Horizon Longitude ${ }^{\mathrm{TM}}$ system (Medtronic - 2600 Sofamor Danek Drive, Memphis, TN 38132).

The patient was under general anesthesia in the prone position with the abdomen uncovered. Identification of the entry point was made with fluoroscopic control. An incision of approximately $2 \mathrm{~cm}$ was made in the skin, slightly lateral to the pedicle entry point. We used a dilation tube (smaller diameter) to move soft tissues away from the entry point. The needle/punch, guide wire, and cannulated auger with the appropriate diameter and length (transpedicular) were successively placed under fluoroscopic control. Subsequently, the cannulated screw was placed through the dilator. This sequence of steps was repeated for each screw. Rods of suitable lengths were placed and shaped, as necessary, by a cranial incision, with the help of a guide. (Figure 3)

Subsequent to the placement of the rods, we proceeded to distract and lock them. A control image was performed to check 
the positioning of screws, rods, and the restoration of the sagittal alignment. The dilators were removed, and the skin was closed. Postoperatively, the patients received antibiotic prophylaxis for 48 hours. The patient was allowed to stand after 24 hours and return to daily activities within two weeks.

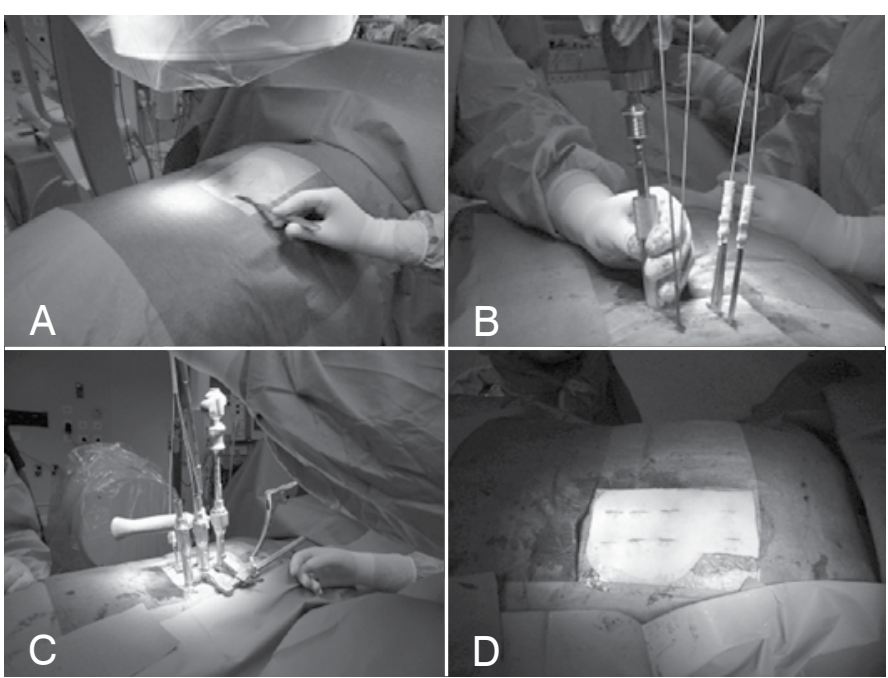

Figure 3. Surgical technique: A) Preoperative marking; B) Placement of the screws; C) Distraction after placement of the rod; D) Postoperative incisions.

\section{RESULTS}

All patients were treated with percutaneous pedicle fixation. The mean operative time was 81 minutes (minimum of 69, maximum of 95 ). The mean intraoperative blood loss was $85 \mathrm{ml}$ (minimum of 75 , maximum of $155 \mathrm{ml}$ ). Hospitalization time was on average seven days (minimum of 5 , maximum of 11 days). All patients were followed up as outpatients for an average period of seven months (minimum of three, maximum of 14 months). The preoperative Cobb angle averaged $16.9^{\circ}\left(5.3^{\circ}-31.7^{\circ}\right)$, postoperatively it was $4.9^{\circ}$, which represents an improvement of about $86 \%$. (Figure 4 and 5) At the end of follow-up it was $8.2^{\circ}$. The percentage of mean preoperative reduction of the vertebral body height was $39.8 \%$ (31.6\% to $61.6 \%)$ and $10.3 \%$ postoperatively, representing an improvement of about $29.5 \%$. At the final follow-up visit, it was $13.2 \%$. The percentage of mean preoperative anterior wedging of the vertebral body was $37.4 \%$ (27.1\% to $57.2 \%$ ) and $20.3 \%$ postoperatively, representing an improvement of about $171 \%$. At the final follow-up visit, it was $24.1 \%$. The percentage of compression of the spinal canal was $28.5 \%$ (8.4 to 53.8). At the final follow-up visit, it was $13.9 \%$. (Table 2 )

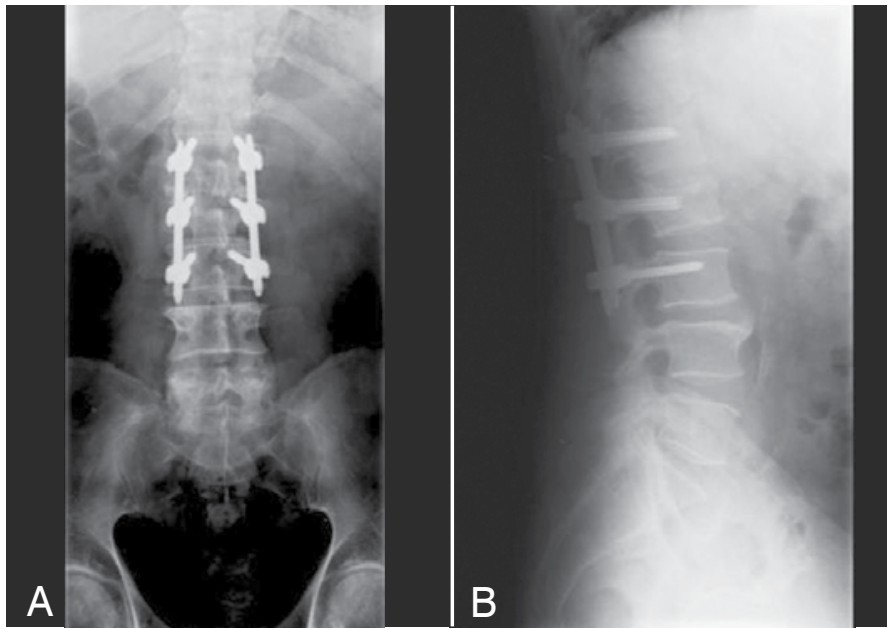

Figure 4. Postoperative radiograph: A) AP, B) Lateral.
The average clinical evaluation with the Oswestry disability index was $18 \%$ (excellent). Of the 23 patients treated, 19 showed no disabilities (0-20\%), and four had moderate disability (21-40\%). None showed a worsening of neurological status, infection, or fixation failure.

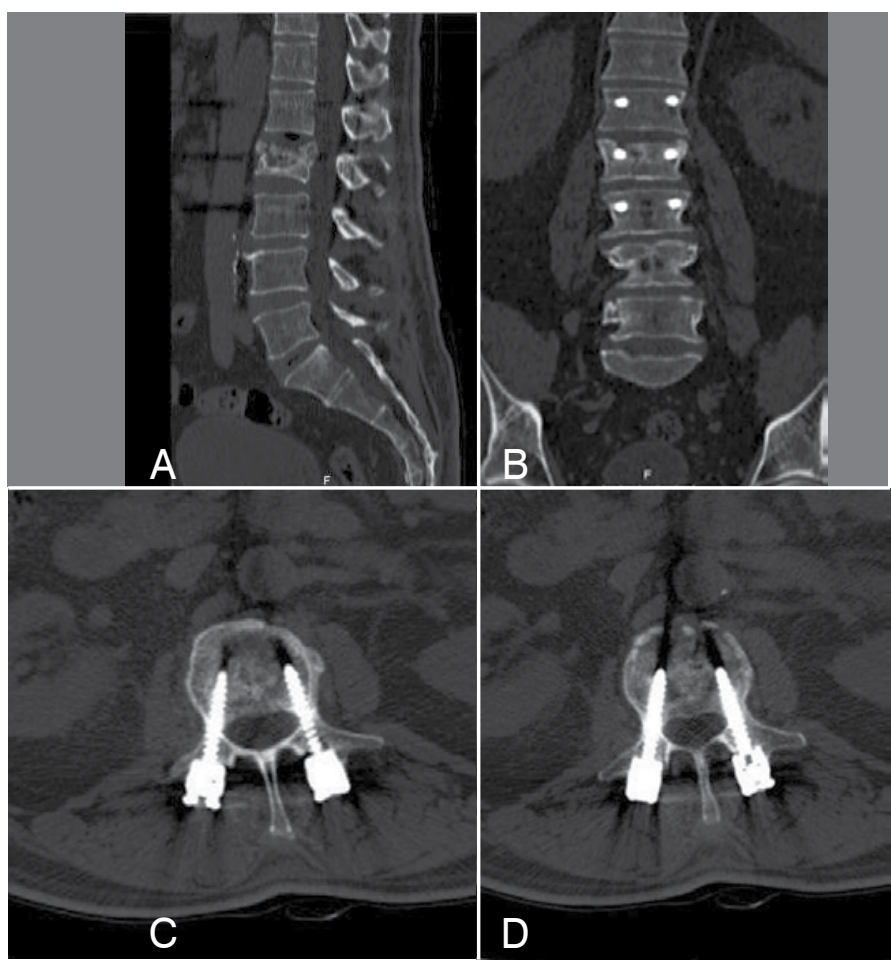

Figure 5. Postoperative CAT of a type L2 burst fracture. A) Sagittal, B) Coronal, C and D) Axial.

Table 2. Imaging evaluation results.

\begin{tabular}{c|c|c|c|c}
\hline & $\begin{array}{c}\text { Kyphosis } \\
\text { (Cobb) }\end{array}$ & $\begin{array}{c}\text { Reduction of } \\
\text { vertebral body } \\
\text { height (\%) }\end{array}$ & $\begin{array}{c}\text { Anterior } \\
\text { compression } \\
(\%)\end{array}$ & $\begin{array}{c}\text { Compression of } \\
\text { the spinal canal } \\
(\%)\end{array}$ \\
\hline Preoperative & $\begin{array}{c}16.9 \\
(5.3-31.7)\end{array}$ & $\begin{array}{c}39.8 \\
(31.6-61.6)\end{array}$ & $\begin{array}{c}37.4 \\
(27.8-57.2)\end{array}$ & $\begin{array}{c}28.5 \\
(8.4-53.8)\end{array}$ \\
\hline Postoperative & 4.9 & 10.3 & 20.3 & 10.8 \\
\hline End of follow-up & $8.7(8.2)$ & $13.2(26.6)$ & $24.1(13.3)$ & $13.9(14.6)$ \\
\hline
\end{tabular}

\section{DISCUSSION}

The first descriptions of the use of plates and pedicle screws to treat thoracolumbar fractures appeared in 1963.11 This kind of fixation with the open posterior approach is associated with a high morbidity and extensive damage to the paravertebral muscle. On the other hand, minimally invasive approaches, such as percutaneous pedicle fixation, dramatically decreased the extent of iatrogenic muscle injury.

Kim et al. ${ }^{8}$ demonstrated that percutaneous pedicle fixation causes less damage to the paravertebral muscle than open fixation techniques.

In a multicenter, prospective, randomized study, Siebenga et al. ${ }^{4}$ demonstrated the advantages of surgical treatment over conservative treatment for thoracolumbar burst fractures with no neurological deficits. The study showed an $8.2^{\circ}$ average improvement of kyphosis in patients undergoing surgical treatment in contrast to about $4.1^{\circ}$ worsening of kyphosis observed in patients treated conservatively. The result in the clinical assessment by the visual analogue scale of pain (VAS pain) was: 72 for conservative treatment, 87 for surgical treatment; "VAS spine": 61 for conservative treatment, 82 for surgical treatment; and RMDQ 
(Roland-Morris Disability Questionnaire): nine for conservative treatment, three for surgical treatment, by which they conclude that surgically treated patients also showed better clinical outcomes. At the end of the treatment, $85 \%$ of surgically treated patients returned to work, whereas only $38 \%$ of the conservatively treated patients returned to work.

Percutaneous pedicle fixation has been widely used as a complementary technique for lumbar fusion in degenerative pathology. ${ }^{11}$ In this study, the percutaneous pedicle fixation technique was used as a single fixation system of the $\mathrm{AO}$ type (A.3) thoracolumbar fracture.

In clinical evaluation, we used the Oswestry Disability Index and obtained a final average of $18 \%$ (minimal disability), better than the results published by Wei et al. ${ }^{12}$ with a reported average of $34.1 \%$ (moderate disability).

The time of surgery (81 minutes) and blood loss $(85 \mathrm{ml})$ were also lower than those reported in open pedicle fixation surgery, with a mean of 153 minutes and $828 \mathrm{ml}$, respectively, in the study by Verlaan et al. ${ }^{13}$

The average correction of the Cobb angle was $8.2^{\circ}$, very similar to results published by Wen-Fei et al. ${ }^{14}$ in a study of percutaneous pedicle fixation of thoracolumbar fractures without neurological deficits (with a mean Cobb angle correction of $8.9^{\circ}$ ) and the results published by Verlaan et al. ${ }^{13}$ in a review of the surgical treatment of thoracolumbar fractures by classical transpedicular fixation (with a mean Cobb angle correction of $8.1^{\circ}$ ).

We can also see in our study that the results for the recovery of the vertebral body height $(29.5 \%)$, recovery of the anterior wedging $(17.1 \%)$, and of the spinal canal $(14.6 \%)$ are identical to those published Wei et al. ${ }^{12}$ in a study on thoracolumbar burst fractures with classical transpedicular fixation.
Regarding instrumentation without fusion, a prospective, randomized study compared pedicle instrumentation with and without fusion, ${ }^{15,16}$ and demonstrated better results in the group without fusion.

However, some studies show that in AO type (A.3) fractures with a high degree of comminution of the vertebral body and high percentage of anterior vertebral wedging, pedicle fixation with fusion seems to have better results. Even in the absence of scientific evidence of the absolute necessity of fusion, specific instruments currently exist for percutaneous fixation that make fusion possible.

\section{CONCLUSION}

The percutaneous pedicle fixation technique presents radiological, clinical, and functional results that are significantly better than the published results with conservative treatment.

This intervention, assisted by fluoroscopy, proved to be a technique with a high accuracy and reliability, with results similar to those reported in studies with the classical transpedicular fixation regarding the deformity correction, but superior with regard to blood loss, postoperative rehabilitation, and return to the activities of daily living.

The results of this study show that this is a valid, safe, and effective treatment for (A3) thoracolumbar burst fractures without neurological deficits.

All authors declare no potential conflict of interest concerning this article.

\section{REFERENCES}

1. Denis F, Armstrong GW, Searls K, Matta L. Acute thoracolumbar burst fractures in the absence of neurologic deficit. A comparison between operative and nonoperative treatment. Clin Orthop Relat Res. 1984:(189):142-9.

2. Domenicucci M, Preite R, Ramieri A, Ciappetta P, Delfini R, Romanini L. Thoracolumbar fractures without neurosurgical involvement: surgical or conservative treatment? J Neurosurg Sci. 1996:40(1):1-10.

3. McLain RF. The biomechanics of long versus short fixation for thoracolumbar spine fractures. Spine (Phila Pa 1976). 2006;31(Suppl 11):S70-9.

4. Siebenga J, Leferink VJ, Segers MJ, Elzinga MJ, Bakker FC, Haarman HJ, et al. Treatment of traumatic thoracolumbar spine fractures: a multicenter prospective randomized study of operative versus nonsurgical treatment. Spine (Phila Pa 1976). 2006;31(25):2881-90.

5. Thomsen K, Christensen FB, Eiskjaer SP, Hansen ES, Fruensgaard S, Bünger CE. 1997 Volvo Award winner in clinical studies. The effect of pedicle screw instrumentation on functional outcome and fusion rates in posterolateral lumbar spinal fusion: a prospective, randomized clinical study. Spine (Phila Pa 1976).1997;22(24):2813-22.

6. Weber BR, Grob D, Dvorák J, Müntener M. Posterior surgical approach to the lumbar spine and its effect on the multifidus muscle. Spine (Phila Pa 1976). 1997;22(15):1765-72.

7. Magerl FP. Stabilization of the lower thoracic and lumbar spine with external skeletal fixation. Clin Orthop Relat Res. 1984;(189):125-41.

8. Kim DY, Lee SH, Chung SK, Lee HY. Comparison of multifidus muscle atrophy and trunk extension muscle strength: percutaneous versus open pedicle screw fixation.Spine (Phila Pa 1976). 2005;30(1):123-9.
9. McCormack T, Karaikovic E, Gaines RW. The load sharing classification of spine fractures. Spine (Phila Pa 1976). 1994;19(15):1741-4

10. Keynan O, Fisher CG, Vaccaro A, Fehlings MG, Oner FC, Dietz J, ety al. Radiographic measurement parameters in thoracolumbar fractures: a systematic review and consensus statement of the spine trauma study group. Spine (Phila Pa 1976). 2006:31(5):E156-65

11. Roy-Camille $R$, Roy-Camille $M$, Demeulenaere $C$. [Plate fixation of dorsolumbar vertebral metastases]. Nouv Presse Med. 1972 Oct 21;1(37):2463-6.

12. Wei FX, Liu SY, Liang CX, Li HM, Long HQ, Yu BS, Chen BL, Chen KB. Transpedicular fixation in management of thoracolumbar burst fractures: monosegmental fixation versus short-segment instrumentation. Spine (Phila Pa 1976). 2010;35(15):E714-20

13. Verlaan JJ, Diekerhof $\mathrm{CH}$, Buskens E, van der Tweel I, Verbout AJ, Dhert WJ, et al. Surgical treatment of traumatic fractures of the thoracic and lumbar spine: a systematic review of the literature on techniques, complications, and outcome. Spine (Phila Pa 1976). 2004;29(7):803-14

14. NiWF, Huang $Y X, C h i Y L, X u H Z$, Lin $Y$, Wang $X Y$, et al. Percutaneous pedicle screw fixation for neurologic intact thoracolumbar burst fractures. J Spinal Disord Tech. 2010;23(8):530-7.

15. Wang ST, Ma HL, Liu CL, Yu WK, Chang MC, Chen TH. Is fusion necessary for surgically treated burst fractures of the thoracolumbar and lumbar spine?: a prospective, randomized study. Spine (Phila Pa 1976). 2006:31(23):2646-52.

16. NiWF, Huang $Y X, C h i Y L, X u H Z$, Lin $Y$, Wang $X Y$, et al. Percutaneous pedicle screw fixation for neurologic intact thoracolumbar burst fractures. J Spinal Disord Tech. 2010;23(8):530-7. 